\title{
Influence of Hormones on mRNA Abundance of Enzymes Related Lipid Metabolism in Longissimus Dorsi Muscle in vitro
}

\author{
${ }^{1}$ Lian Hong-Xia, ${ }^{2} \mathrm{Lu}$ De-Xun, ${ }^{2} \mathrm{Gao}$ Min and ${ }^{1} \mathrm{Gao}$ Teng-Yun \\ ${ }^{1}$ College of Animal Science and Veterinary Medicine, \\ Henan Agricultural University, 450002 Zhengzhou, China \\ ${ }^{2}$ Institute of Animal Nutrition, \\ Inner Mongolian Academy of Agricultural and Animal Science, 010031 Huhhot, China
}

\begin{abstract}
The current study was performed to examine the response of the enzymes related lipid metabolism gene to hormonal stimulation in pig muscle tissue from finishing pigs. Longissimus dorsi muscle was collected and muscle tissue explants (approximately $100 \mathrm{mg}$ ) were prepared by sterile technique in finishing barrows $(100.5 \pm 5.3 \mathrm{~kg} \mathrm{BW})$ of Rongchang. A in vitro system was established to investigate the regulation of Insulin (INS), Somatotropin (ST), Epinephrine (Epi) and Glucagon (GCG) on Lipoprotein Lipase (LPL), Acetyl-CoA Carboxylase (ACC), Fatty Acid Synthase (FAS) and Hormone Sensitive Lipase (HSL) gene expression to determine whether there was any potential for the manipulation of the Intramuscular Fat (IMF) deposit in Longissimus dorsi muscle of pig. The experiment was conducted with an orthogonal design with a $\mathrm{L}_{9}\left(3^{4}\right)$ and each treatment had three replicates. Results showed that ST significantly affected HSL and FAS mRNA abundance $(p<0.01)$ and $\mathrm{NNS}$ influenced LPL and ACC mRNA abundance $(\mathrm{p}<0.01)$, respectively. This results suggested that the combination of hormones (INS; $1 \times 10^{-5} \mathrm{M}$, ST; $5 \times 10^{-11} \mathrm{M}$, Epi; $1 \times 10^{-6} \mathrm{M}$, GCG; $1 \times 10^{-7} \mathrm{M}$, INS; $1 \times 10^{-7} \mathrm{M}$, ST; $5 \times 10^{-9} \mathrm{M}$, Epi; $1 \times 10^{-6} \mathrm{M}$, GCG; $1 \times 10^{-6} \mathrm{M}$, INS; $1 \times 10^{-7} \mathrm{M}$, ST; $5 \times 10^{-9} \mathrm{M}$, Epi; $1 \times 10^{-6} \mathrm{M}$, GCG; $1 \times 10^{-6} \mathrm{M}$ ) could increase IMF content by increasing LPL, ACC and FAS mRNA expression and at the same time, the combination of hormones (INS; $1 \times 10^{-7} \mathrm{M}$, ST; $5 \times 10^{-10} \mathrm{M}$, Epi; $1 \times 10^{-7} \mathrm{M}$, GCG; $1 \times 10^{-8} \mathrm{M}$ ) had higher IMF content by decreasing HSL mRNA expression. It could be concluded that the combination of hormones (NN; $1 \times 10^{-5}$, ST; $5 \times 10^{-9}$, Epi; $1 \times 10^{-7}$, GCG; $1 \times 10^{-8}$ ) could improve IMF content in finishing pigs.
\end{abstract}

Key words: Insulin, lipoprotein lipase, mRNA abundance, muscle explants, quantitative real-time PCR, China

\section{INTRODUCTION}

Flavour and tenderness are key components contributing to a good eating experience. Intramuscular fat extracted from the Longissimus muscle was related to flavour and juiciness (Fernandez et al., 1999) with marbling related to percent intramuscular fat (De Campeneere et al., 1999). Sutdies showed that one of Chinese local species, Rongchang had higher intramuscular fat content in muscle (Pang et al., 2006).

Muscle tissues and cells undergo a regulated growth and differentiation processes as well as substrate utilization and energy partitioning were affected by a range of factors (Hocquette et al., 1998a, b). Recently, the (signaling) interaction between myogenic cells and adipocytes had been found which was considered as a significant role in regulation of the rate and extent of adipogenesis, myogenesis and lipogenesis/lipolysis (Fruhbeck et al., 2001; Diamond, 2002). Studies showed that Insulin (NNS), Somatotropin (ST), Epinephrine (Epi) and Glucagon (GCG) were hormones participating in the processes of lipogenesis/lipolysis in animals (Hillgartner et al., 1995).

Conventional PCR has been shown to convincingly detect the presence of some enzymes in muscles such as Lipoprotein Lipase (LPL) in muscle tissues of bovine and psoas muscle of rat (Hocquette et al., 1998b), Acetyl-CoA Carboxylase $(\mathrm{ACC})$ in muscle tissues of human and soleus muscle of rats (Abu-Elheiga et al., 2003, 2001), Fatty Acid Synthetase (FAS) in BC3H-1 myocytes (Zhang and Kiechle, 2006) and Hormone Sensitive Lipase (HSL) in soleus muscle of rats (Langfort et al., 2003, 2000). Salati found that some hormones regulated these enzymes mRNA levels of pig in vitro (Salati and Clarke, 1986).

However, the major drawback of conventional PCR lies in the difficulty in generating quantitative data in relation to the input template because of the exponential kinetics of PCR amplification and the end point detection

Corresponding Author: Lian Hong-Xia, College of Animal Science and Veterinary Medicine, Henan Agricultural University, 450002 Zhengzhou, China 
of the amplified product (Orlando et al., 1998). The recent introduction of quantitative real-time Reverse Transcription-polymerase Chain Reaction (qRT-PCR) technology, a variant of conventional PCR has largely solved. This problem and can be considered as an alternative to conventional PCR. This variant of PCR measures the product formation in real time by means of fluorogenic probes and was acknowledged to be extremely sensitive (Heid et al., 1996), making it an invaluable tool in all areas of biology where sensitivity and rapidity of detection are critical to the end user (Orlando et al., 1998).

The current study was performed to examine the response of the $L P L, A C C, F A S$ and $H S L$ gene in Longissimus dorsi muscle of Rongchang pigs to hormonal stimuli by quantitative real-time PCR and to determine whether there was any potential for the hormonal manipulation of the Intramuscular Fat (IMF) deposition in pig muscle.

\section{MATERIALS AND METHODS}

Longissimus dorsi muscle isolation: Three Rongchang barrows were used (initial BW: $80.6 \pm 2.8 \mathrm{~kg}$ ). They were fed a corn-soybean meal diet for 1 month. Pigs were separately housed in a semi-confinement, cement-floor facility in 3 adjacent pens $(2.0 \times 4.0 \mathrm{~m})$ and slaughtered when the body weight reached at about $100.5 \pm 5.3 \mathrm{~kg}$. During the experimental period, all the pigs had a free access to water and a $11.94 \%$ CP corn-soybean meal diet containing $0.45 \%$ truly digestible lysine and $12.96 \mathrm{MJ} \mathrm{ME}$ $\mathrm{kg}^{-1}$ according to recommendations of GB 7223-1987 (Nutrient Requirements of Rongchang Swine in 1987). Pigs were exsanguinated by a sterile scalpel and samples of Longissimus dorsi muscle were immediately collected from the 10 th rib on the right side and rapidly placed into an incubator vessel containing sterile Hank's buffer (0.35 $\mathrm{g} \mathrm{L}^{-1}$ sodium bicarbonate, $\mathrm{pH7}$.4, H6136, Sigma).

Longissimus dorsi muscle incubations: Longissimus dorsi muscle explants were rinsed with Hank's buffer, sheared and seeded on $25 \mathrm{~cm}^{2}(50 \mathrm{~mL})$ tissue culture flasks (Greiner bio-one, German) at a density of 2 explant $\mathrm{cm}^{-2}(1 \times 1 \mathrm{~cm})$ in cabinet (Class-Biological Safety Cabinet, Forma, USA) maintained in incubator at $37^{\circ} \mathrm{C}$ in a humidified, $5 \% \quad \mathrm{CO}_{2}$ atmosphere (Series-CO ${ }_{2}$ Water Jacketed Incubator, Thermo Forma, USA) and $2 \mathrm{~h}$ later culture media was perfused along the wall of flasks which was Dulbecco's modified Eagle medium/F12 (DMEM/F12, 12500-062, Gibco BRL, USA) containing 20\% (v/v) fetal bovine serum (FBS, 10088-141, Gibco BRL, USA) supplemented with sodium bicarbonate $\left(1.2 \mathrm{~g} \mathrm{~L}^{-1}\right)$, the antibiotics penicillin $\mathrm{G}\left(10 \mathrm{mg} \mathrm{L}^{-1}\right)$ and streptomycin (10 $\mathrm{mg} \mathrm{L}^{-1}$ ). When explants surrounded by cells (days 6-8), cultures were changed to DMEM/F12 containing $10 \%(\mathrm{v} / \mathrm{v})$. Culture medium were changed every 3 days and in the mean while culture was observed by inverted microscope (IX70-131, Olympus, Japan). Until $80 \%$ cells confluency (days 14-16), cultures then were shifted to serum-free media for $6 \mathrm{~h}$, supplemented with $1.5 \%$ Bovine Serum Albumin (BSA, M20231B, Maverick, Australia) and different hormone including insulin (I6634, Sigma, USA), somatotropin (S8648, Sigma, USA), epinephrine (E4250, Sigma, USA) and glucagon (G3157, Sigma, USA) according to a orthogonal design with a $\mathrm{L}_{9}\left(3^{4}\right)$ (Table 1$)$. Each treatment had three replicates and hormone levels of each treatment were shown in Table 2.

RNA isolation and cDNA synthesis: After culture, cells were washed with prewarmed Hank's buffer and total RNA was extracted using RNAiso total RNA extraction reagent (D312, TaKaRa, Dalian, China). RNA concentrations were determined by measuring absorbance at $260 \mathrm{~nm}$ using the UV/visible spectrphotometer (DU-640, Beckman, U.S.A.) and its purity was verified spectrophotometrically at $260 / 280 \mathrm{~nm}$. Electrophoresis of total RNA through a $1 \%$ agarose gel followed by ethidium bromide staining to allow visualization of 28 and $18 \mathrm{~S}$ ribosomal RNA (rRNA) was used to assess the integrity of RNA. After RNA integrity was assessed, samples were DNased to remove any contaminating genomic DNA using a commercially DNase (RNase Free, D2215, TaKaRa, Dalian, China). One microgram of total RNA was then reverse-transcribed to produce the first strand complementary DNA (cDNA) using TaqMan reverse transcription reagents (DRR035, TaKaRa, Dalian, China) and following the protocol recommended by the manufacturer. Random oligo (dT) was used as primers in cDNA synthesis.

Design of PCR primers for qRT-PCR: All qRT-PCR primers were designed with the Primer Express software

Table 1: The orthogonal experiment design of INS, ST, Epi and GCG

\begin{tabular}{lcccc}
\hline & Factors & & & \\
& & & \\
No. of treatments & $\mathrm{INS}^{1}(\mathrm{M})$ & $\mathrm{ST}^{2}(\mathrm{M})$ & $\mathrm{Epi}^{3}(\mathrm{M})$ & $\mathrm{GCG}^{4}(\mathrm{M})$ \\
\hline 1 & $1 \times 10^{-7}$ & $5 \times 10^{-11}$ & $1 \times 10^{-8}$ & $1 \times 10^{-8}$ \\
2 & $1 \times 10^{-7}$ & $5 \times 10^{-10}$ & $1 \times 10^{-7}$ & $1 \times 10^{-7}$ \\
3 & $1 \times 10^{-7}$ & $5 \times 10^{-9}$ & $1 \times 10^{-6}$ & $1 \times 10^{-6}$ \\
4 & $1 \times 10^{-6}$ & $5 \times 10^{-11}$ & $1 \times 10^{-7}$ & $1 \times 10^{-6}$ \\
5 & $1 \times 10^{-6}$ & $5 \times 10^{-10}$ & $1 \times 10^{-6}$ & $1 \times 10^{-8}$ \\
6 & $1 \times 10^{-6}$ & $5 \times 10^{-9}$ & $1 \times 10^{-8}$ & $1 \times 10^{-7}$ \\
7 & $1 \times 10^{-5}$ & $5 \times 10^{-11}$ & $1 \times 10^{-6}$ & $1 \times 10^{-7}$ \\
8 & $1 \times 10^{-5}$ & $5 \times 10^{-10}$ & $1 \times 10^{-8}$ & $1 \times 10^{-6}$ \\
9 & $1 \times 10^{-5}$ & $5 \times 10^{-9}$ & $1 \times 10^{-7}$ & $1 \times 10^{-8}$ \\
\hline
\end{tabular}

${ }^{1}$ Insulin; ${ }^{2}$ Somatotropin; ${ }^{3}$ Epinephrine; ${ }^{4}$ Glucagon 
Table 2: Primers and TaqMan probe sequences used for real-time quantitative PCR

\begin{tabular}{|c|c|c|}
\hline Genes (GenBank Accession No.) & Primer and probe sequence & Predicted size (bp) \\
\hline \multirow[t]{3}{*}{$\beta-\operatorname{actin}^{1}(\mathrm{U} 07786)$} & Forward: 5'-CTCTTCCAGCCCTCCTTCCT-3' & \multirow[t]{3}{*}{87} \\
\hline & Reverse: 5'GATGTCCACGTCGCACTTCA-3' & \\
\hline & Probe: 5'-(FAM) TCCTGCGGCATCCACGAGACCACC (Eclipse)-3' & \\
\hline \multirow[t]{3}{*}{$\mathrm{HSL}^{2}$ (NM_214315) } & Forward: 5'-TCCAAGTGTGTCAGTGCCTATG-3' & \multirow[t]{3}{*}{121} \\
\hline & Reverse: 5'-GGAGGTCTCGGAAGAGCAGG-3' & \\
\hline & Probe: 5'-(FAM) TGTCCCGCCGCACCAGTCCCA (Eclipse)-3' & \\
\hline \multirow[t]{3}{*}{ LPL $^{3}$ (NM_214286) } & Forward: 5'-GGACCTAACTTCGAGTATGCAGAA-3' & \multirow[t]{3}{*}{90} \\
\hline & Reverse: 5'-CCCTCTGGTGAATGTGTGTAAGA-3' & \\
\hline & Probe: 5'-(FAM) CCGCCTTTCTCCCGACGACGCAG (Eclipse)-3' & \\
\hline \multirow[t]{3}{*}{$\mathrm{FAS}^{4}$ (AY952929) } & Forward: 5'-CTACCTTGTGGATCACTGCATAGA-3' & \multirow[t]{3}{*}{114} \\
\hline & Reverse: 5'-GGCGTCTCCTCCAAGTTCTG-3' & \\
\hline & Probe: 5'-(FAM) CGTGCCAGCGTCTTCCAGGTCAGC-(Eclipse) 3' & \\
\hline \multirow[t]{3}{*}{$\mathrm{ACC}^{5}(\mathrm{AF} 175308)$} & Forward: 5'-CTGACATGCTGACGTACACTGA-3' & \multirow[t]{3}{*}{102} \\
\hline & Reverse: 5'-TCCAAGCTACCATGCCAATCTC-3' & \\
\hline & Probe: 5'-(FAM)-TCCTCCTGGAAGCCTGTTCATGTGGACC-(Eclipse) 3' & \\
\hline
\end{tabular}

${ }^{1}$ Sus scrofa $\beta$-actin, mRNA; ${ }^{2}$ Sus scrofa hormone-sensitive Lipase (LIPE), mRNA; ${ }^{3}$ Sus scrofa Lipoprotein Lipase (LPL), mRNA; ${ }^{4}$ Sus scrofa Fatty Acid Synthase (FASN), mRNA; ${ }^{5}$ Sus scrofa acetyl-CoA carboxylase, mRNA

(Version 2.0; Applied Biosystems) using design parameters specified for real-time PCR. The primers were custom-synthesized by TaKaRa (Dalian, China). The designs of the primers used in the present study were derived from cDNA sequences already present in the database (National Center for Biotechnology Information, NCBI). Pig specific $\beta$-actin as an endogenous control, LPL, ACC, FAS and HSL forward and reverse primer and TaqMan detection probe were synthesized using published GenBank sequences (Table 2). Specificity of all the primers was tested by two methods: The first by searching the homologous DNA sequences with the GenBank BLAST tool and the second by amplifying the respective target DNA by conventional PCR and visualizing the amplification on $2.0 \%$ agarose gels with ethidium bromide.

Quantitative real-time-PCR: Real-time quantitative PCR was used to measure the quantity of LPL, ACC, FAS and HSL mRNA relative to the quantity of beta actin in total RNA isolated from Longissimus muscle tissue of pigs. Measurement of the relative quantity of cDNA was carried out using TaqMan Universal PCR Master Mix (TaKaRa, Dalian, China), $200 \mathrm{nM}$ concentration of the appropriate forward and reverse primers, $120 \mathrm{nM}$ concentration of appropriate TaqMan detection probe and $2 \mu \mathrm{L}$ of the cDNA mixture. Assays were performed in an real-time system (MJ Research, $\mathrm{NC}$ ), using thermal cycling parameters recommended by the manufacturer $\left(10 \mathrm{sec}\right.$ at $95^{\circ} \mathrm{C}$ followed by 45 cycles of $5 \mathrm{sec}$ at $95^{\circ} \mathrm{C}, 15 \mathrm{sec}$ at $57.5^{\circ} \mathrm{C}, 6 \mathrm{sec}$ at $72^{\circ} \mathrm{C}$ and $1 \mathrm{sec}$ at $80^{\circ} \mathrm{C}$ ). Relative expression of LPL, ACC, FAS and HSL was normalized with the beta actin endogenous control and expressed in arbitrary units. Titration of LPL, ACC, FAS and HSL and beta actin primer against increasing amounts of cDNA gave linear responses with slopes of $0.268-0.301$.
The relative quantified results of all the target genes were described by $2^{-\Delta C}, \Delta C_{T}=C_{T \text {, Target }}-C_{T \text {, Actin }}$ which $C_{T}$ (the threshold cycle) indicates the fractional cycle number at which the amount of amplified target reaches a fixed threshold (Livak and Schmittgen, 2001).

Statistical analysis: Data were analyzed by ANOVA with the General Linear Model (GLM) procedure of SAS software (SAS, 2000) in an orthogonal design with three replicates and repeated measures over time.

\section{RESULTS}

Specificity of all the primers was tested by amplifying the respective target DNA by conventional PCR and visualizing the amplification on $2.0 \%$ agarose gels with ethidium bromide (Fig. 1 and 2).

The effects of insulin, somatotropin, epinephrine and glucagon on mRNA abundance of LPL were shown in Table 3 and 4. It was obtained that the degree of effect on LPL mRNA was ranged with $\mathbb{I N S}>\mathrm{GCG}>$ Epi $>$ ST. LPL mRNA level was significantly affected by insulin $(p<0.01)$, somatotropin $(\mathrm{p}<0.05)$, epinephrine $(\mathrm{p}<0.01)$ and glucagon $(p<0.01)$. The optimal combination of was INS3 ST1 Epi3 GCG2 (NNS; $1 \times 10^{-5} \mathrm{M}$, ST; $5 \times 10^{-11} \mathrm{M}$, Epi; $1 \times 10^{-6} \mathrm{M}$, GCG; $\left.1 \times 10^{-7} \mathrm{M}\right)$.

The effects of hormones on mRNA abundance of ACC were shown in Table 5 and 6 . Insulin affected ACC mRNA abundance most $(\mathrm{p}<0.01)$ following with somatotropin $(p<0.01)$, epinephrine $(p<0.01)$ and glucagon $(\mathrm{p}<0.05)$ in turn. The combination of INS1 ST3 Epi3 GCG3 was optimal (INS; $1 \times 10^{-7} \mathrm{M}$, ST; $5 \times 10^{-9} \mathrm{M}$, Epi; $1 \times 10^{-6}$ M, GCG; $\left.1 \times 10^{-6} \mathrm{M}\right)$.

FAS, the enzyme complex involved in the de novo synthesis was of long chain fatty acids which was a key intermediate at the branch point between the glycolytic 


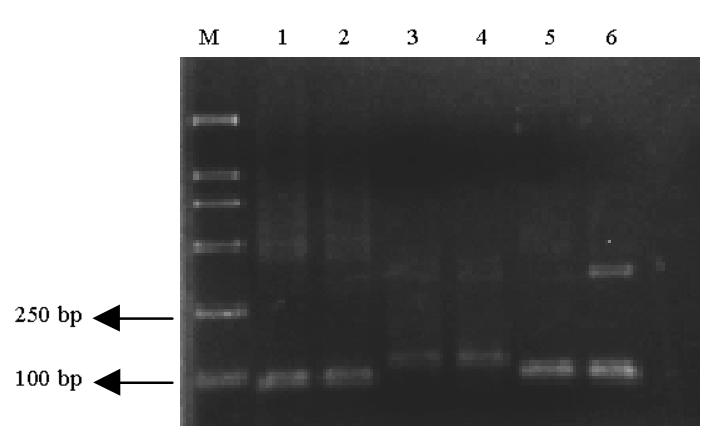

Fig. 1: Conventional PCR and visualizing the amplification on $2.0 \%$ agarose gels with ethidium bromide showing the specificity of the primers designed in the present study of $\beta$-actin, HSL and LPL. 1, 2: $\beta$-actin RT-PCR product; 3, 4: HSL RT-PCR product; 5, 6: LPL RT-PCR product

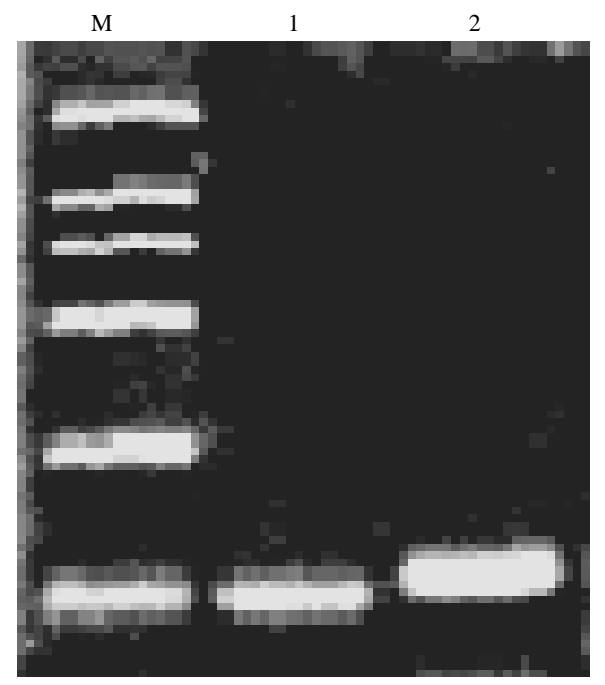

Fig. 2: Conventional PCR and visualizing the amplification on $2.0 \%$ agarose gels with ethidium bromide showing the specificity of the primers designed in the present study of ACC and FAS. 1: ACC RT-PCR product; 2: FAS RT-PCR product

pathway and triacylglycerol synthesis. The effects of insulin, somatotropin, epinephrine and glucagon on mRNA level of FAS were shown in Table 7 and 8 . The degree of effect on FAS mRNA was ranged with $\mathrm{ST}>\mathrm{GCG}>\mathrm{NSS}>$ Epi. Somatotropin $(\mathrm{p}<0.01)$ significantly affected FAS mRNA level. The optimal combination of was INS1 ST3 Epi3 GCG3 (INS; $1 \times 10^{-7} \mathrm{M}$, ST; $5 \times 10^{-9}$ M, Epi; $1 \times 10^{-6} \mathrm{M}, \mathrm{GCG} ; 1 \times 10^{-6} \mathrm{M}$ ).

The effects of insulin, somatotropin, epinephrine and glucagon on mRNA abundance of HSL were shown in
Table 3: Analysis of variances of the orthogonal experimental results of LPL

\begin{tabular}{lcrrrr}
\multicolumn{6}{c}{$\mathrm{mRNA} \times 10^{-3}$} \\
\hline Sources & Sum of squares & df & \multicolumn{1}{c}{ Mean $^{2}$} & \multicolumn{1}{c}{$\mathrm{F}$} & $\mathrm{p}$-values \\
\hline Corrected Model & 824.850 & 8 & 103.106 & 9.324 & 0.000 \\
Intercept & 1090.486 & 1 & 1090.486 & 98.618 & 0.000 \\
$\mathrm{INS}^{1}$ & 272.106 & 2 & 136.053 & 12.304 & 0.000 \\
$\mathrm{ST}^{2}$ & 121.444 & 2 & 60.722 & 5.491 & 0.014 \\
$\mathrm{Epi}^{3}$ & 220.287 & 2 & 110.143 & 9.961 & 0.001 \\
$\mathrm{GCG}^{4}$ & 211.013 & 2 & 105.507 & 9.541 & 0.001 \\
Error & 199.038 & 18 & 11.058 & - & - \\
Total & 2114.375 & 27 & - & - & - \\
Corrected total & 1023.888 & 26 & - & - & - \\
\hline
\end{tabular}

Table 4: Single factor investigation of the orthogonal experimental results of LPL mRNA $\times 10^{-3}$

\begin{tabular}{lcrrrr}
\hline \multicolumn{3}{c}{$\begin{array}{l}\text { Hormonal } \\
\text { concentrations }\end{array}$} & \multicolumn{3}{c}{$95 \% \mathrm{CI}$} \\
Factors & $(\mathrm{M})$ & Mean & SE & Lower bound & Upper bound \\
\hline $\mathrm{INS}^{1}$ & $1 \times 10^{-7}$ & 3.207 & 1.108 & 0.878 & 5.535 \\
& $1 \times 10^{-6}$ & 5.158 & 1.108 & 2.829 & 7.487 \\
& $1 \times 10^{-5}$ & 10.701 & 1.108 & 8.372 & 13.030 \\
$\mathrm{ST}^{2}$ & $5 \times 10^{-11}$ & 9.107 & 1.108 & 6.778 & 11.435 \\
& $5 \times 10^{-10}$ & 3.946 & 1.108 & 1.617 & 6.274 \\
& $5 \times 10^{-9}$ & 6.013 & 1.108 & 3.685 & 8.342 \\
$\mathrm{Epi}^{3}$ & $1 \times 10^{-8}$ & 4.134 & 1.108 & 1.806 & 6.463 \\
& $1 \times 10^{-7}$ & 4.543 & 1.108 & 2.215 & 6.872 \\
& $1 \times 10^{-6}$ & 10.388 & 1.108 & 8.059 & 12.717 \\
$\mathrm{GCG}^{4}$ & $1 \times 10^{-8}$ & 3.481 & 1.108 & 1.152 & 5.810 \\
& $1 \times 10^{-7}$ & 10.143 & 1.108 & 7.815 & 12.472 \\
& $1 \times 10^{-6}$ & 5.441 & 1.108 & 3.112 & 7.770 \\
\hline
\end{tabular}

Table 5: Analysis of variances of the orthogonal experimental results of ACC mRNA $\times 10^{-4}$

\begin{tabular}{lrrrrc}
\hline Sources & Sum of squares & df & \multicolumn{1}{c}{ Mean $^{2}$} & \multicolumn{1}{c}{$\mathrm{F}$} & p-values \\
\hline Corrected Model & 1022.918 & 8 & 127.865 & 8.992 & 0.000 \\
Intercept & 2017.095 & 1 & 2017.095 & 141.854 & 0.000 \\
$\mathrm{INS}^{1}$ & 430.025 & 2 & 215.013 & 15.121 & 0.000 \\
$\mathrm{ST}^{2}$ & 266.070 & 2 & 133.035 & 9.356 & 0.002 \\
$\mathrm{Epi}^{3}$ & 218.496 & 2 & 109.248 & 7.683 & 0.004 \\
$\mathrm{GCG}^{4}$ & 108.326 & 2 & 54.163 & 3.809 & 0.042 \\
Error & 255.951 & 18 & 14.220 & - & - \\
Total & 3295.964 & 27 & - & - & - \\
Corrected total & 1278.869 & 26 & - & - & - \\
\hline
\end{tabular}

Table 6: Single factor investigation of the orthogonal experimental results of $\mathrm{ACC}$ mRNA $\times 10^{-4}$

\begin{tabular}{lcrrrr}
\hline \multicolumn{3}{c}{$\begin{array}{l}\text { Hormonal } \\
\text { concentrations }\end{array}$} & & \multicolumn{3}{c}{$95 \% \mathrm{CI}$} \\
Factors & $(\mathrm{M})$ & Mean & \multicolumn{1}{c}{$\mathrm{SE}$} & Lower bound & Upper bound \\
\hline $\mathrm{INS}^{1}$ & $1 \times 10^{-7}$ & 14.104 & 1.257 & 11.464 & 16.745 \\
& $1 \times 10^{-6}$ & 7.147 & 1.257 & 4.506 & 9.787 \\
& $1 \times 10^{-5}$ & 4.679 & 1.257 & 2.038 & 7.320 \\
$\mathrm{ST}^{2}$ & $5 \times 10^{-11}$ & 4.944 & 1.257 & 2.304 & 7.585 \\
& $5 \times 10^{-10}$ & 8.367 & 1.257 & 5.726 & 11.007 \\
& $5 \times 10^{-9}$ & 12.619 & 1.257 & 9.978 & 15.260 \\
$\mathrm{Epi}^{3}$ & $1 \times 10^{-8}$ & 6.498 & 1.257 & 3.857 & 9.139 \\
& $1 \times 10^{-7}$ & 6.769 & 1.257 & 4.128 & 9.410 \\
& $1 \times 10^{-6}$ & 12.663 & 1.257 & 10.023 & 15.304 \\
$\mathrm{GCG}^{4}$ & $1 \times 10^{-8}$ & 7.070 & 1.257 & 4.429 & 9.711 \\
& $1 \times 10^{-7}$ & 7.390 & 1.257 & 4.749 & 10.031 \\
& $1 \times 10^{-6}$ & 11.470 & 1.257 & 8.829 & 14.111 \\
\hline
\end{tabular}

${ }^{1}$ Insulin; ${ }^{2}$ Somatotropin; ${ }^{3}$ Ep inephrine; ${ }^{4}$ Glucagon

Table 9 and 10. Somatotropin affected HSL mRNA abundance significantly $(\mathrm{p}<0.01)$ following with glucagon $(p<0.01)$, epinephrine $(p<0.01)$ and insulin $(p<0.01)$ in turn. 
Table 7: Analysis of variances of the orthogonal experimental results of FAS mRNA $\times 10^{-3}$

\begin{tabular}{lcrrrl}
\hline Sources & Sum of squares & df & Mean $^{2}$ & \multicolumn{1}{c}{ F } & p-values \\
\hline Corrected model & 296.029 & 8 & 37.004 & 3.185 & 0.020 \\
Intercept & 571.044 & 1 & 571.044 & 49.148 & 0.000 \\
$\mathrm{INS}^{1}$ & 37.449 & 2 & 18.724 & 1.612 & 0.227 \\
$\mathrm{ST}^{2}$ & 175.227 & 2 & 87.613 & 7.541 & 0.004 \\
$\mathrm{Epi}^{3}$ & 24.327 & 2 & 12.163 & 1.047 & 0.371 \\
$\mathrm{GCG}^{4}$ & 59.026 & 2 & 29.513 & 2.540 & 0.107 \\
Error & 209.141 & 18 & 11.619 & - & - \\
Total & 1076.214 & 27 & - & - & - \\
Corrected total & 505.170 & 26 & - & - & - \\
\hline
\end{tabular}

Table 8: Single factor investigation of the orthogonal experimental results of FAS mRNA $\times 10^{-3}$

\begin{tabular}{lccccc}
\hline \multirow{3}{*}{$\begin{array}{c}\text { Hormonal } \\
\text { concentrations } \\
\text { Factors }\end{array}$} & & \multicolumn{3}{c}{$95 \% \mathrm{CI}$} \\
\hline $\mathrm{INS}^{1}$ & $1 \times 10^{-7}$ & 5.823 & 1.136 & 3.436 & 8.210 \\
& $1 \times 10^{-6}$ & 4.964 & 1.136 & 2.577 & 7.352 \\
& $1 \times 10^{-5}$ & 3.009 & 1.136 & 0.622 & 5.396 \\
$\mathrm{ST}^{2}$ & $5 \times 10^{-11}$ & 2.704 & 1.136 & 0.317 & 5.092 \\
& $5 \times 10^{-10}$ & 2.892 & 1.136 & 0.505 & 5.279 \\
& $5 \times 10^{-9}$ & 8.200 & 1.136 & 5.813 & 10.587 \\
$\mathrm{Epi}^{3}$ & $1 \times 10^{-8}$ & 3.790 & 1.136 & 1.403 & 6.177 \\
& $1 \times 10^{-7}$ & 4.076 & 1.136 & 1.688 & 6.463 \\
& $1 \times 10^{-6}$ & 5.931 & 1.136 & 3.544 & 8.318 \\
$\mathrm{GCG}^{4}$ & $1 \times 10^{-8}$ & 5.486 & 1.136 & 3.098 & 7.873 \\
& $1 \times 10^{-7}$ & 2.516 & 1.136 & 0.128 & 4.903 \\
& $1 \times 10^{-6}$ & 5.796 & 1.136 & 3.408 & 8.183 \\
\hline
\end{tabular}

Table 9: Analysis of variances of the orthogonal experimental results of HSL mRNA $\times 10^{-3}$

\begin{tabular}{lccrrc}
\hline Sources & Sum of squares & df & Mean $^{2}$ & \multicolumn{1}{c}{ F } & p-values \\
\hline Corrected model & $244.255^{b}$ & 8 & 30.532 & 14.739 & 0.000 \\
Intercept & 221.708 & 1 & 221.708 & 107.029 & 0.000 \\
$\mathrm{INS}^{1}$ & 40.921 & 2 & 20.460 & 9.877 & 0.001 \\
$\mathrm{ST}^{2}$ & 72.290 & 2 & 36.145 & 17.449 & 0.000 \\
$\mathrm{Epi}^{3}$ & 63.830 & 2 & 31.915 & 15.407 & 0.000 \\
$\mathrm{GCG}^{4}$ & 67.215 & 2 & 33.607 & 16.224 & 0.000 \\
Error & 37.287 & 18 & 2.071 & - & - \\
Total & 503.250 & 27 & - & - & - \\
Corrected total & 281.542 & 26 & - & - & - \\
\hline
\end{tabular}

Table 10: Single factor investigation of the orthogonal experimental results of HSL mRNA $\times 10^{-3}$

\begin{tabular}{lccccc}
\hline \multicolumn{3}{c}{$\begin{array}{c}\text { Hormonal } \\
\text { concentrations }\end{array}$} & & & \multicolumn{3}{c}{$95 \% \mathrm{CI}$} & \\
Factors & $(\mathrm{M})$ & Mean & $\mathrm{SE}$ & Lower bound & Upper bound \\
\hline $\mathrm{INS}^{1}$ & $1 \times 10^{-7}$ & 1.761 & 0.480 & 0.753 & 2.769 \\
& $1 \times 10^{-6}$ & 2.252 & 0.480 & 1.244 & 3.260 \\
& $1 \times 10^{-5}$ & 4.583 & 0.480 & 3.575 & 5.591 \\
$\mathrm{ST}^{2}$ & $5 \times 10^{-11}$ & 5.047 & 0.480 & 4.039 & 6.055 \\
& $5 \times 10^{-10}$ & 1.106 & 0.480 & 0.098 & 2.113 \\
& $5 \times 10^{-9}$ & 2.444 & 0.480 & 1.437 & 3.452 \\
$\mathrm{Epi}^{3}$ & $1 \times 10^{-8}$ & 2.092 & 0.480 & 1.084 & 3.100 \\
& $1 \times 10^{-7}$ & 1.492 & 0.480 & 0.484 & 2.500 \\
& $1 \times 10^{-6}$ & 5.012 & 0.480 & 4.004 & 6.020 \\
$\mathrm{GCG}^{4}$ & $1 \times 10^{-8}$ & 1.383 & 0.480 & 0.375 & 2.391 \\
& $1 \times 10^{-7}$ & 5.051 & 0.480 & 4.043 & 6.059 \\
& $1 \times 10^{-6}$ & 2.162 & 0.480 & 1.154 & 3.170 \\
\hline
\end{tabular}

${ }^{1}$ Insulin; ${ }^{2}$ Somatotropin; ${ }^{3}$ Epinephrine, Glucagon

The combination of INS1 ST2 Epi2 GCG1 (INS; $1 \times 10^{-7} \mathrm{M}$, ST; $5 \times 10^{-10} \mathrm{M}$, Epi; $1 \times 10^{-7} \mathrm{M}$, GCG; $1 \times 10^{-8} \mathrm{M}$ ) was superior to others.

\section{DISCUSSION}

Lipoprotein Lipase (LPL) catalysed the rate-limiting step of adipose tissue lipogenesis and was thought to control intramuscular triacylglycerol degradation. The reason for this belief was the finding under various conditions of a direct relationship between lipoprotein lipase activity and triacylglycerol depletion in muscle (Oscai et al., 1990). LPL was of particular interest in tissues of meat-producing animals because LPL controls the partitioning of fatty acids between adipose tissue and muscle (Hocquette et al., 1998a). The levels of LPL transcripts are positively related to LPL activity in bovine tissues (Hocquette et al., 1998b). Therefore, LPL activity may affect beef carcass quality by regulating the available substrates for either muscle or marbling development.

Aceryl-Coenzyme A (acetyl-CoA) Carboxylase (ACC) Catalyzes the synthesis of malonyl-CoA, a metabolite that plays a pivotal role in the synthesis of fatty acids as the donor of C2 units (Thampy, 1989) and in the oxidation of fatty acid as the regulator of the mitochondrial shuttle system (McGarry and Brown, 1997). Hence, ACC links fatty acid and carbohydrate metabolism through the shared intermediated acetyl-CoA, the product of pyruvate dehydrogenase. Increasing evidence suggests that it play major roles in regulating the rates of fatty acid synthesis and oxidation, respectively as they relate to energy homeostasis (Abu-Elheiga et al., 2001). They are under a strict regulation by diet, hormones and other physiological factors (Allred and Reilly, 1996). These regulators manifested their actions at the levels of gene expression and by modulating enzyme activities either through ST allosteric activation by citrate or by covalent modification, phosphorylation dephosphorylation of specific serine residues (Kim, 1997; Mabrouk et al., 1990). Mabrouk reported that Glucagon or epinephrine injection of fasted/refed rats yielded carboxylase with lower specific activity (1.4 or 1.9 units $\mathrm{mg}^{-1}$, respectively), higher phosphate content (6.4 or $6.7 \mathrm{~mol}$ of $\mathrm{Pi} / \mathrm{mol}$ of subunit, respectively) and mainly in the octameric state (Mr approximately $2 \times 10^{6}$ ) (Diamond, 2002; Yin et al., 1998). Fatty Acid Synthase (FAS) was a key enzyme in the lipogenic pathway that catalyzes all the reactions in the conversion of acetyl-CoA and malonyl-CoA to palmitic acid. Fatty acid synthase activity, mRNA levels and gene transcription are exquisitely sensitive to nutritional and hormonal manipulations (Hillgartner et al., 1995). For example, the previous studies indicate that Somatotropin (ST) dramatically attenuates the stimulatory effect of insulin on FAS mRNA abundance and gene transcription in rat liver and in 3T3-F442A adipocytes (Yin et al., 1998). An impressive body of evidence indicates that ST dramatically decreases lipogenesis in adipose tissue of 
growing pigs. This decrease occurs as the result of a ST-dependent reduction in insulin sensitivity and responsiveness in adipocytes (Etherton and Bauman, 1998). The available data indicate that the pST-dependent decrease in lipogenesis was due to a marked decrease in the activity of several insulin-stimulated lipogenic enzymes including FAS (Donkin et al., 1996).

Hormone Sensitive Lipase (HSL) catalyses the ratelimiting step of adipose tissue lipolysis. HSL was thus one of the enzymes determining whole-body fuel availability and it accounts for most of the detectable lipolysis in the post-absorptive state (Langin et al., 1996). The amount of HSL was considered to be the rate-limiting factor in adipocyte lipolysis. Any variation in HSL expression will therefore modulate the extent of adipose tissue lipid mobilization (Grober et al., 1997). HSL was present in skeletal muscle cells and was more abundantly expressed in oxidative than in glycolytic muscle fibres. Both adrenaline and contractions stimulate muscle HSL activity and the effects of the two stimuli are partially additive. Adrenaline and contractions enhance muscle HSL activity by different signaling mechanisms. Langfort demonstrated the presence of the neutral lipase HSL by Western blotting in muscle which controls triacylglycerol breakdown in adipose tissue (Langfort et al., 1999). Furthermore, it was shown that analysed under conditions optimal for HSL, neutral lipase activity in muscle can be increased by adrenaline as well as by muscle contractions and these increases were abolished by the presence of anti-HSL anti-body during analysis (Lang fort et al., 1999, 2000).

\section{CONCLUSION}

The results suggested that the combination of hormones (INS; $1 \times 10^{-5} \mathrm{M}$, ST; $5 \times 10^{-11} \mathrm{M}$, Epi; $1 \times 10^{-6} \mathrm{M}$, GCG; $1 \times 10^{-7} \mathrm{M}, \mathrm{INS} ; 1 \times 10^{-7} \mathrm{M}, \mathrm{ST} ; 5 \times 10^{-9} \mathrm{M}, \mathrm{Epi}$; $1 \times 10^{-6} \mathrm{M}$, GCG; $1 \times 10^{-6} \mathrm{M}, \mathrm{INS} ; 1 \times 10^{-7} \mathrm{M}, \mathrm{ST} ; 5 \times 10^{-9} \mathrm{M}$, Epi; $1 \times 10^{-6} \mathrm{M}, \mathrm{GCG} ; 1 \times 10^{-6} \mathrm{M}$ ) could increase IMF content by increasing LPL, ACC and FAS mRNA expression and at the same time the combination of hormones (INS; $1 \times 10^{-7} \mathrm{M}$, ST; $5 \times 10^{-10} \mathrm{M}$, Epi; $1 \times 10^{-7} \mathrm{M}$, GCG; $1 \times 10^{-8} \mathrm{M}$ ) had higher IMF content by decreasing HSL mRNA expression. It could be concluded that the combination of hormones (INS; $1 \times 10^{-5} \mathrm{M}$, ST; $5 \times 10^{-9} \mathrm{M}$, Epi; $1 \times 10^{-7} \mathrm{M}$, GCG; $1 \times 10^{-8} \mathrm{M}$ ) could improve IMF content in finishing pigs.

\section{ACKNOWLEDGEMENTS}

The researchers sincerely acknowledge for the financial support provided by 973 Major State Basic Research Development Program of China (No.
2004CB1 17500) and Modern Agro-industry Technology Research System (CARS-37). The researchers thank Mr. Liu Zuohua and Yang Feiyun for animal experiments.

\section{REFERENCES}

Abu-Elheiga, L., M.M. Matzuk, K.A.H. Abo-Hashema and S.J. Wakil, 2001. Continuous fatty acid oxidation and reduced fat storage in mice lacking acetyl-CoA carboxylase 2. Science, 291: 2613-2616.

Abu-Elheiga, L., O.H. Wonkeun, P. Kordari and S.J. Wakil, 2003. Acetyl-CoA carboxylase 2 mutant mice are protected against obesity and diabetes induced by high-fat/high-carbohydrate diets. Proc. Natl. Acad. Sci., 100: 10207-10212.

Allred, J.B. and K.E. Reilly, 1996. Short term regulation of acetyl CoA carboxylase in tissues of higher animals. Prog. Lipid Res., 35: 371-385.

De Campeneere, S., L.O. Fiems, G. van de Voorde, J.M. Vanacker, C.V. Boucque and D.I. Demeyer, 1999. Estimation of chemical carcass composition from 8th rib characteristics with Belgian blue double-muscled bulls. Meat Sci., 51: 27-33.

Diamond, F., 2002. The endocrine function of adipose tissue. Growth Genet. Hormones, 18: 17-23.

Donkin, S.S., P.Y. Chiu, D. Yin, I. Louveau and B.S. Swencki, 1996. Porcine somatotrophin differentially down-regulates expression of the GLUT4 and fatty acid synthase genes in pig adipose tissue. J. Nutr., 126: 2568-2577.

Etherton, T.D. and D.E. Bauman, 1998. The biology of somatotropin in growth and lactation of domestic animals. Physiol. Rev., 78: 745-761.

Fernandez, X., G. Monin, A. Talmant, J. Mourot and B. Lebret, 1999. Influence of intramuscular fat content on the quality of pig meat: Composition of the lipid fraction and sensory characteristics of longissimus lumborum. Meat Sci., 53: 59-65.

Fruhbeck, G., J. Gomez-Ambrosi, F.J. Muruzabal and M.A. Burrell, 2001. The adipocyte: A model for integration of endocrine and metabolic signaling in energy metabolism regulation. Am. J. Physiol. Endocrinol. Metab., 280: E827-E847.

Grober, J., H. Laurell, R. Blaise, B. Fabry, S. Schaak, C. Holm and D. Langin, 1997. Characterization of the promoter of human adipocyte hormone-sensitive lipase. Biochem. J., 328: 453-461.

Heid, C.A., J. Stevens, K. J. Livak and P.M. Williams, 1996. Real time quantitative PCR. Genome Res., 6: 986-994.

Hillgartner, F.B., L.M. Salati and A.G. Goodridge, 1995. Physiological and molecular mechanisms involved in nutritional regulation of fatty acid synthesis. Physiol. Rev., 75: 47-76. 
Hocquette, J.F., I. Ortigues-Marty, D. Pethick, P. Herpin and X. Fernandez, 1998a. Nutritional and hormonal regulation of energy metabolism in skeletal muscles of meat-producing animals. Livest. Prod. Sci., 56: 115-143.

Hocquette, J.F., B. Graulet and T. Olivecrona, 1998b. Lipoprotein lipase activity and mRNA levels in bovine tissues. Comp. Biochem. Physiol. Biochem. Mol. Biol., 121: 201-212.

Kim, K.H., 1997. Regulation of mammalian acetylcoenzyme A carboxylase. Annu. Rev. Nutr., 17: 77-99.

Langfort, J., T. Ploug, J. Ihlemann, M. Saldo, C. Holm and H. Galbo, 1999. Expression of hormone sensitive lipase and its regulation by adrenaline in skeletal muscle. Biochem. J., 340: 459-465.

Langfort, J., T. Ploug, J. Thlemann, C. Holm and H. Galbo, 2000. Stimulation of hormone-sensitive lipase activity by contractions in rat skeletal muscle. Biochem. J., 351: 207-214.

Langfort, J., M. Donsmark, T. Ploug, C. Holm and H. Galbo, 2003. Hormone-sensitive lipase in skeletal muscle: Regulatory mechanisms. Acta Physiol. Scand., 178: 397-403.

Langin, D., C. Holm and M. Lafontan, 1996. Adipocyte hormone sensitive lipase: A major regulator of lipid metabolism. Proc. Nutr. Soc., 55: 93-109.

Livak, K.J. and T.D. Schmittgen, 2001. Analysis was of relative gene expression data using real-time quantitative PCR and the 2(-Delta Delta $\mathrm{C}(\mathrm{T})$ ) Method. Methods, 25: 402-408.

Mabrouk, G.M., I.M. Helmy, K.G. Thampy and S.J. Wakil, 1990. Acute hormonal control of acetyl-CoA carboxylase. The roles of insulin, glucagon and epinephrine. J. Biol. Chem., 265: 6330-6338.
McGarry, J.D. and N.F. Brown, 1997. The mitochondrial carnitine palmitoyltransferase system from concept to molecular analysis. Eur. J. Biochem., 244: 1-14.

Orlando, C., P. Pinzani and M. Pazzagli, 1998. Developments in quantitative PCR. Clin. Chem. Lab. Med., 36: 255-269.

Oscai, L.B., D.A. Essing and W.K. Palmer, 1990. Lipase regulation of muscle triglyceride hydrolysis. J. Applied Physiol., 69: 1571-1577.

Pang, W.J., L. Bai and G.S. Yan, 2006. Relationship among H-FABP gene polymorphism, intramuscular fat content and adipocyte lipid droplet content in main pig breeds with different genotypes in Western China. Acta Genet. Sin., 33: 515-524.

SAS, 2000. SAS User's Guide: Statistics Version 15. SAS Institute, Cary, NC.

Salati, L.M. and S.D. Clarke, 1986. Fatty acid inhibition of hormonal induction of acetyl-coenzyme: A carboxylase in hepatocyte monolayers. Arch. Biochem. Biophys., 246: 82-89.

Thampy, K.G., 1989. Formation of malonyl coenzyme A in rat heart Identification and purification of an isozyme of A carboxylase from rat heart. J. Biol. Chem., 264: 17631-17634.

Yin, D., S.D. Clarke, J.L. Peters and T.D. Etherton, 1998. Somatotropin dependent decrease in fatty acid synthase mRNA abundance in 3T3-F442A adipocytes was the result of a decrease in both gene transcription and mRNA stability. Biochem. J., 331: 815-820.

Zhang, X. and F.L. Kiechle, 2006. Fatty acid synthase and its mRNA concentrations are decreased at different times. Ann. Clin. Lab. Sci., 36: 185-193. 